West of England." Proc. Cotteswold Nat. F.C., vol. xvi, part 2, pp. I5I-193, and plates xvi-xvii.

rgro. Hudleston, W. H._-" Dorset-Inland." Geologv in the Field, part 2, pp. 365-38r.

igro. Monckton, H. W.-." The Dorset Coast." Td., pp. 382-413.

rgIo. Buckman, S. S.--"Certain Jurassic (Lias-Oolite) Strata of South Dorset and their Correlation." Quart. Fourn. Geol. Soc., vol. 1xvi, pp. 52.89 .

1910. _Lertain Jurassic ("Inferior Oolite') Species of Ammonites and Brachiopoda." Id., pp. 90-108, and plates ix-xii.

1912. RIChardson, L., and BUTT, Rev. WALTER-"Excursion to Bridport, Dorset." Proc. Cotteswold Nat. F.C., vol. xviii, part I, pp. $3^{r-38}$, and plates iv-vi.

19I2. _ and PARIS, E. T._-"On the Stratigraphical and Geographical Distribution of the Inferior Oolite Echinoids of the West of England : Supplement." Id., pp. 73-82, and plate viii.

\title{
REPORT OF AN EXCURSION TO GREENHITHE AND STONE.
}

Saturday, April 25 Th, IgI4.

By S. Priest, F.G.S., Director of the Excursion.

ABout 40 members arrived at Greenhithe at 2.37 p.m., and proceeded to London Road, where the chief features of the district were briefly described.

In the neighbourhood of Greenhithe the Chalk rises to about Ioo ft. above O.D., and at this height is overlain by a well defined terrace of gravel, extending from Stone Place, $x_{4} 4 \mathrm{ft}$. above O.D., to Dartford Brent. The gravel terrace is intersected by two valleys which unite near Stone Court Cottages, where the surface falls to the $25 \mathrm{ft}$. contour. The thickest part of the gravel lies roughly along the line of London Road. In the Stone Court pits (east and west of Cotton Lane) a few feet of Thanet Sand separate the Pleistocene deposits from the Chalk, but along its northern limit the gravel rests directly upon the Chalk, and its base contains much coarse material, principally large unrolled chalk-flints. The drift appears to lie in a channel excavated in the Chalk after the demudation of the overlying Tertiaries.

The constituents of these gravels are principally flints and cherts derived from the Lower Greensand, Chalk and Eocene 
beds. The proportion of northern or Thames-borne material is very small in comparison with the abundance of Darent-borne drift. The arrangement of the material is simple, agreeing well with what has been noted at Dartford Heath. All the pits show two phases of deposits: (r) Upper Division, fairly horizontal beds, gravels and loams alternately, sometimes interdigitating, the loams thickening into stiff red brick-earths towards the surface. (:) Lower Division, Current-bedded fine sands and gravels, the bedding planes often accentuated by layers of black oxides of iron and manganese. Some additional features of general interest may be noted.

I. The gravels and sands at Hillhouse and Martin's pits show rich bands of fragments of an Eocene species of Cvrena, associated with coarse quartz grit.

2. Shallow loam-filled channels, across the horizontal upper beds, thus furnishing another point of agreement with Dartford Heath.

3. The highest gravel consists of drifted surface material (very coarse at Castle Cross pit) with pockets of soil and calcined fints, probably indicating cooking-sites of Neolithic or later age.

4. Near the chalk floor, especially towards the northern bank of the channel, large flints occur, showing a brecciated upper surface. These have generally been described as "shattered flints." The jagged brecciated surface is deeply scored.

In all the pits "sand-pipes" are left standing as hummocks of unworked waste, where the sands appear to lie in saucer-shaped hollows. The dip of the adjacent beds towards the central depression indicates subsidence caused by the solution of the underlying chalk. Some sections, recently exposed, show where these pipes have continued to act as natural drainage channels. The pipes sometimes contain hard cores of stony loam surrounded by pea-gravel and sand. In other cases the core is a sand and the casing consists of hard stony loam.

Notes on special features of the various pits visited are appended with references to the sheets of the 6-in Ordnance Map.

Howe Hill Pit.-(Sheet 9 N.E., $2 \mathrm{I} / 3$ miles E. of Dartford.)

Here were a few large blocks of shelly conglomerate containing Aporrhais, Pectunculus, Panopara, Natica and fish teeth, an association of fossils which suggest derivation from the Basement Bed of the London Clay. Some dark lumps of hard ironstone containing quartz grit, with a siliceous deposit in cavities, are common here. Dr. Strahan has kindly inspected samples and suggests that they may have been derived from the Lower Greensand or Wealden Beds. Some fossiliferous ironstones obtained here were regarded by some of the party as possibly fragments of Lenham (Pliocene) Beds. Mr. Barrow thought this uniikely, and Mr. H. A. Allen has ascertained that the casts appear to be Cyrena and Cerithium. Mr. E. T. Newton agrees that 
these shelly ironstones are probably of Woolwich and Reading age.

This pit has yielded Bunter quartzites and a small pebble of reticulated chert, similar to hundreds which the Director has seen in the Bunter Beds of Staffordshire, and which are there regarded as derivative. Mr. Leach, who states that he has obtained similar pebbles from Dartford Heath and from the Shooters Hill gravel (in the latter there is no admixture of northern drift), thinks they do not come directly from the Bunter Beds, but possibly from the Lower Greensand.

This pit shows upwards of $43 \mathrm{ft}$. of clean, sharp sand and gravels, and, on the west face, two well defined superficial loamfilled channels appear in section, one $165 \mathrm{ft}$. in width, showing at the centre upwards of $1 \mathrm{I} \mathrm{ft}$. of deposits, as follow :

Thin gravelly soil.

Red loam.

Green and brown clay.

Pebbles.

The finest material occupied the centre of the channel, the sides being slightly pebbly.

Castle Cross Pit adjoins the former pit and affords the best views of the upper gravel deposits, especially where they are intersected by later deposits. The pit also gives valuable evidence of the position of the main channel parallel roughly with London Road. On either side of the road the Chalk is near the surface. In the middle of the pit sand and gravel $55 \mathrm{ft}$. deep were cut through; these deposits at the mouth of the tunnel were $42 \mathrm{ft}$. thick; $60 \mathrm{ft}$. southward, $37 \mathrm{ft}$. ; $60 \mathrm{ft}$. further south, $35 \mathrm{ft}$. The Chalk therefore rises southward, and shows on the surface near Woodlands. The drift here contains relatively large transported boulders. The following were measured :-

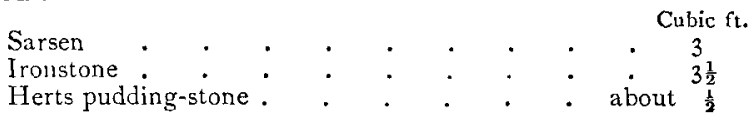

Three large hummocks remaining at the back of the pit are the loamy cores of sand-pipes in the drift, left isolated by the removal of the valuable gravel.

The southern face of the pit showed the following section:-

ft.

Gravelly soil, with flakes, potboilers, and fragments of pottery $\quad 3$

Red gravels and loarns . . . . . I4

Sandy current-bedded gravel . . . . . . . I5 to 20

Light loams and sands with Cyrena fragments . . . . 2

Chalk forming floor of pit.

The deposit immediately above the Chalk is in places a fine sand 5 to $6 \mathrm{ft}$. thick, containing pellets of chalk.

The surface material removed from the south-east part of the 
pit yielded a harvest of calcined flints, fragments of coarse pottery, and rude flint flakes. Mr. G. Barrow states that the pottery with white specks seems identical with that found at the London Docks and of mediæval age.

On returning to London Road the members were surprised at the height attained by the Chalk immediately to the north. Drift deposits were seen also as follows: Horn's Cross Post Office (I $20 \mathrm{ft}$. above O.D.), loamy gravel ; "Fredville" (xoo ft. above O.D.), I $2 \mathrm{ft}$. of ballast on clean sand; THe Nook $(92 \mathrm{ft}$. above O.D.), $24 \mathrm{ft}$. of sands and gravels.

Martin's Pit, opposite Acacia Road, showed $20 \mathrm{ft}$. of drift. Here large Bunter pebbles occur, and the Director has found crumbly septaria with Ditrupa, abundant fragnents of Cyrena, a large Ostrea and a pebble of pink granite. Mr. Gasson here obtained a shark's tooth (Eocene) from the drift.

Tollgate Pit (Scott and Branton).--The section here showed:-

Gravel and stiff red loamy bands

Tertiary pebbles and sharp sand

Thanet sand

Chalk and Bullhead.

Ragstone (Lower Greensand) is abundant in fresh condition. The Tertiary pebbles appear to belong to the Blackheath Beds.

Hill House Pit.-Mr. J. Curd, works foreman, kindly had the floor of this pit cleared and a clean section exposed. The drift consists of current bedded sand and gravel resting on a chalk floor exposed $\mathrm{r} 2 \mathrm{ft}$. below the road level. The Director and Mr. Curd have here obtained Jurassic Belemnites and Gryphæa, probably $G$. arcuata and $G$. dilatato. A bed of crushed shells of Cyrena, about $2 \mathrm{ft}$. thick, was exposed with the ordinary sandy gravel above and below it. In Mr. Whitaker's opinion the Tertiary material seen in this pit might be referred to the Blackheath Beds.

Cotton Lane Pits. - The new pit on the west side of the road was examined. To correct some of the suggestions called forth by a peculiar crater-like aperture in the floor of the pit, the method of working this pit may be recorded. A tunnel was driven under Cotton Lane from the old pit on the east, and, a small area on the west having been "uncallowed," a narrow vertical shaft was cut upwards from the tunnel through solid chalk to the floor of the present pit. The upper part of this shaft was greatly enlarged afterwards, and through it all the material now excavated in the pit is transferred to waggons in the tunnel below.

The specimens of some peculiar flint nodules (apparently shattered and re-cemented by secondary silica) found in this pit have been examined by several geologists, and notes of their opinions are appended.

Mr. Barrow writes : "The peculiarly jagged edged deposit of Proc. Geol. Assoc., Vol. XXVI, Part I, 19I5.] 
silica on the large flints was puzzling and new to most of the members of the Association. The suggestion that occurred was that the silica was an inflling material. A very oozy clay had been deposited on and partly round the top of the large flints, and, as Sorby has shown, when originally deposited the clay contained far more water than was necessary to simply keep it wet; as the excess of water drained off, the clay shrank, and being next the unshrinkable large flint, cracks were formed into which the silica filtered. This silica he regarded as of the same nature as the cement of the normal type of 'pudding-stone,' and sections would be made to ascertain if this was so."

Mr. Whitaker, who had seen similar great cakes of flint in East Kent, thought that secondary silica, accumulating later than the bull-head, had rejoined the fractured flints.

Dr. A. Strahan has communicated the following suggestions : "The large flint shows a tendency to split and flake along more or less parallel lines, as though it had been subjected to pressure, and had developed a rough shear structure."

Some fractured flints, obtained from the sides of a pipe in this pit, were submitted to Mr. J. Reid Moir, who states that the bulbs seen on a few of the specimens are similar to those produced by his experiments on flints in presses, and probably have been produced by pressure in this case.

The party spent a considerable time in this pit examining and discussing its many features of interest, and then walked into Dartford. Tea was obtained at the Bull Hotel, and the President expressed the thanks of the party to the Director for a most interesting excursion.

Mr. A. H. Williams acted as Excursion Secretary.

The following notes on Stone Court Pit, No. 3, are kindly furnished by $\mathrm{Mr}$. R. H. Chandler.

Stone Court Pit, No. 3 , is situated on the west side of Cotton Lane, and at the edge of the first terrace overlooking the alluvial flats of the Thames Valley. The surface is about 120 ft. O.D., and the section exposed shows :

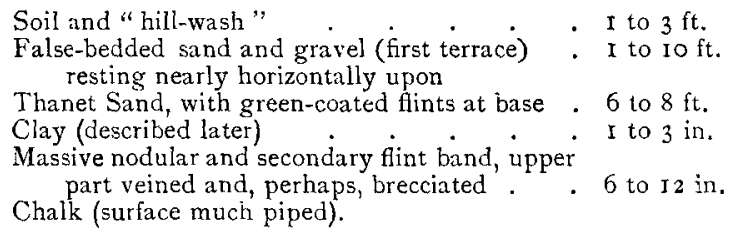

The southern face of the pit showed a pipe about $35 \mathrm{ft}$. wide, into which the Thanet Sand had descended, and it was clearly formed in pre-first terrace times, because the gravel does not sag into it, and the Thanet Sand is cut off horizontally by the gravel; but a more recent visit has shown that where the face has been cut back some further 8 or ro $\mathrm{ft}$., this pipe has at its centre a 
place which has acted as a swallow-hole since the terrace gravels were laid down, because here both the terrace gravel and the overlying " hill-wash" descend for a distance of io ft. Further work will probably show the pipe to deepen in this direction.

At the western corner of the pit a normal pipe was seen, the core being of chocolate-coloured and buff sand, and the whole overrun by "hill-wash"; the sides of the pipe showed the terrace gravel (with the long axes of the pebbles vertical) and Thanet Sand passing vertically downwards, and both pinched out to a lew inches in thickness.

On the lip of this pipe, but resting partly upon Chalk and partly overhanging the pipe, I obtained one of the massive nodular flints from which some flakes had been pressed off by the weight of the descending mass ; below this flint several small flints were shattered, and above it a green-coated flint was fractured. Both the green-coated and the nodular flint show silicious high glaze, and this seems to point that pressure may have something to do with similar glazing on implements, although, perhaps, the descending water may be equally answerable, for, as the following particulars show, a quantity of silica in solution has been in this neighbourhood.

The top of the Chalk here is remarkable for a band of nodular flints, sometimes nearly i $\mathrm{ft}$. thick, and upon them and wrapping round their irregularities on the upper surface there has been deposited secondary silica, which has the appearance of being brecciated and re-cemented or veined with silica (tertiary) of a slightly different structure, since, in weathered examples, ${ }^{*}$ the veins show white and disintegrate before the secondary or the nodular flint.

The suggestion that the secondary flint flowed into cracks in the clay (to be noted later) seems a process rather difficult to follow, because the clay is all above the secondary brecciated band; hence the flint flowed into cracks in the under-surface of the clay. Besides, the existence of innumerable hollow spaces in a definite few inches of clay (as here required), underlying the Thanet Sand, and, perhaps at that time, the rest of the Tertiary Beds, is sufficiently novel to require some proof.

On the other hand, I admit it is equally difficult to see how brecciation took place in the secondary flint without affecting the nodular band to which it is closely amalgamated. From a casual study of some slices under the microscope, it seems that what appears to be clearly brecciation in the hand specimen may really be due to infiltration of the veining material. In age the secondary silica is later than the green coating on the "Bull Head" flints, since Mr. Whitaker stated he had seen a green-coated flint in East Kent clasped by the secondary flint. It seems to the writer

* Weathered nodular flint with the secondary brecciated fint attached is abundant in the gravels of the Northfleet Pits 
possible that the secondary flint may in some part represent the flint dissolved off the "Bull Head" flints, for these are in many places seen to be distinctly worn or dissolved.

I give below a brief description of three slices under the microscope, but the whole subject is worth the investigation of a skilled microscopist.

No. I.-Fragment of a block of nodular and secondary flint from Howe Hill Gravel Pit.

Hand specimen shows junction of black nodular with grey secondary flint. Exterior (top, next to the clay) has the jagged appearance suggesting brecciation.

Nodular Flint.-Near the junction with the secondary the nodular flint is distinctly granular, and at the junction nearly opaque. Away from the junction, and increasing as the granular structure dies out, there are minute discontinuous, sometimes curved and branching, cracks. Broken sponge spicules occur, but the flint is otherwise clear and structureless. $\times$ Nicols reveals some crystalline patches.

Secondary Flint.-The distinction between the nodular and the secondary flint is well marked; the latter contains several different species of foraminifera, and is so crowded with opaque dust and broken spicules as to become only feebly translucent ; it is veined with darker coloured opaque flint containing angular fragments of translucent flint. $\times$ Nicols brings out the contrast between the secondary and the included fragments, but otherwise has little effect.

The actual junction between the nodular and the secondary flint is marked by either a very fine open space or a yellow opaque line (probably iron staining on cortex of nodular before deposition of the secondary flint). No. 3.

No. II.-From Junction Bed, described in Stone Court Pit

Hand specimen shows brecciated appearance, both in section and on surface (top, next to the clay), but under the microscope the more opaque veins pass insensibly into the ordinary secondary flint.

Slide traversed by minute cracks, roughly parallel to each other, and not filled with any veining material.

No. III.-From Junction Bed, described in Stone Court Pit No. 3.

Hand specimen shows on surface (top, next to the clay) the jagged exterior, and section shows the whitish veins to be continuations of the fractures suggested by the jagged surface and roughly parallel to each other. The other section at right angles to the last, and also to the surface, shows a few. Parallel to the surface there are veins (? lines of deposition).

Slide shows dusty secondary flint, veined with brown opaque flint (one vein containing a foraminifer), enclosing angular and 
Proc. Geol. Assoc., vol. XXVI.

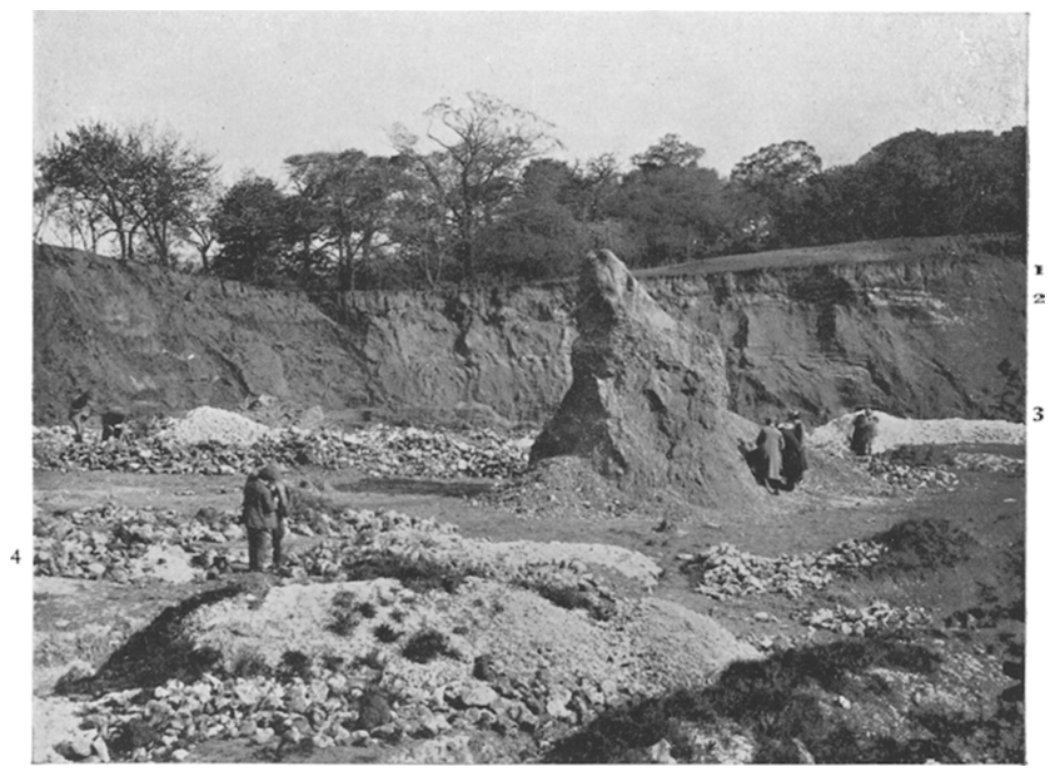

[Photo by T.W. Reader.

A.-Howe Hill Pit, London Road, Stone, Kent.

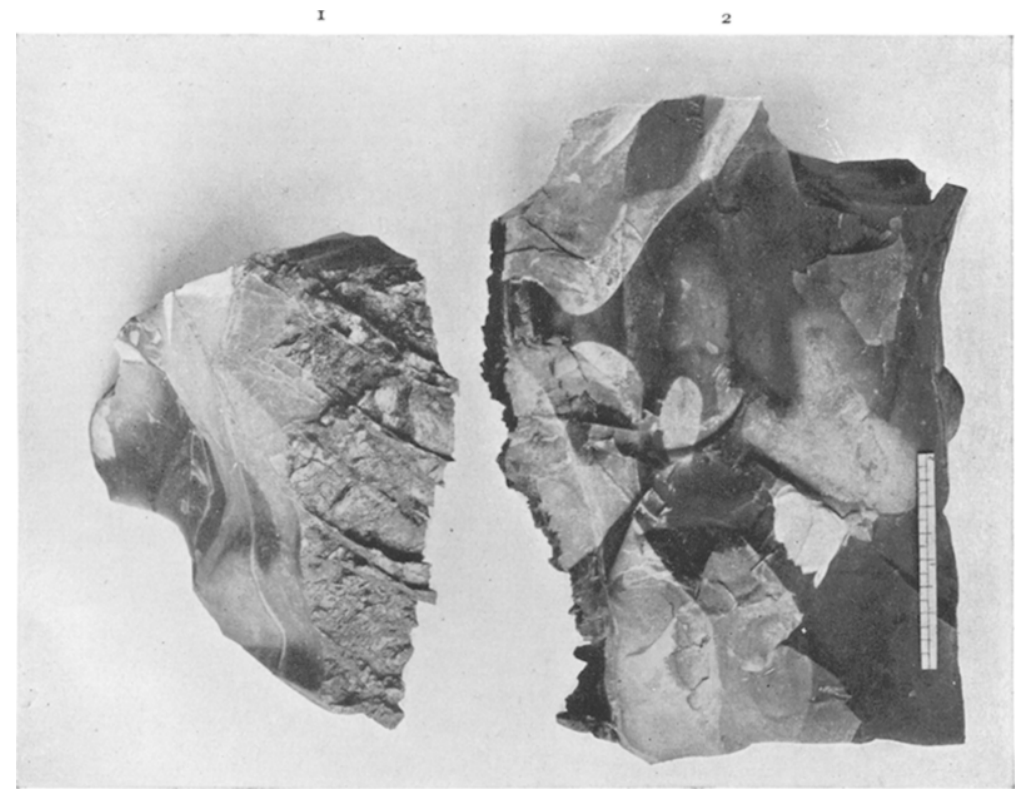

[Photo by E. C. Youens.

B.-Brecciated Flint from Tabular Band, Cotton lane Pit, DARTFORD. 
rounded fragments of secondary flint. The slide presents the same brecciated appearance as parts of No. I.

The details at the base of the Thanet Sand here present peculiarities sufficient to call for brief notice. The Thanet Sand becomes more clayey towards the base, where it contains greencoated flints (mostly small). The green-coated flints in sandy clay rest upon about half an inch of tan-coloured ferruginous meal, succeeded by $\frac{1}{2}$ in. to 3 in. of black, black with white specks, and cream-coloured clayey material. This black and cream band contains many slickensided surfaces. The cream colour and position suggest allophane, but a single analysis has failed to confirm this.

\section{DESCRIPTION OF THE PLATES.}

Plate rOA.-Section in Howe Hill Pit Stone, $\frac{1}{3}$ mile west of Greenhithe Station, Kent.

I. Loam-filled channel of late date cutting across Bed 2.

2. Upper Division, Dartford Heath Gravels (finely-bedded).

3. Lower Division, Dartford Heath Gravels. Much heavy débris near base.

4. Chalk floor.

Plate IOB.-Brecciated Flint from Tabular Band, Cotton Lane Pit (Stone Court Company), near Dartford, Kent.

The specimens show the incorporation of both tabular and nodular flint by deposits of enveloping secondary silica.

Specimen I shows a brecciated surface on right, union of tabular and nodular flint by secondary silica.

Specimen 2. On left, furrowed edge of brecciated surface, well-defined iunction of nodular and tabular fint.

\section{REFERENCES.}

Ordnance Survey Map, 6 inch scale, Kent. Sheet 9, N.E.

Geological Survey Map, $\mathrm{I}$ inch scale, London district. Sheet 4.

I 889. Whitaker, W.- "Geology of London." Mem. Geol. Surv

1910. LeACH, A. L. "North Kent and Adjoining Parts of Surrey." "Geology in the Field," p. 236.

I9i2. Chandeler, R. H., and Leach, A. L.-"On the Dartford Heath Gravel, etc." Proc. Geol. Assoc., vol, xxiii. p. IO2.

I912. PRIEST, S.-"Excursion to Greenhithe." Proc. Geol. Assoc., vol. xxiii, p. 190.

rg13. LEACH, A. L.- "On Buried Channels in the Dartford Heath Gravel." Proc. Geol. Assoc., vol. xxiv, p. 337. 